\title{
Amigos Associados
}

Terminamos mais um ano de muitas conquistas e realizações. Como é do conhecimento de todos vocês, não foi um ano fácil, tanto para os nossos colegas da indústria como da área acadêmica. As crises asiática e da Rússia afetaram seriamente o nosso país, com reflexos significativos na produção local e nas reservas do Brasil.

Como não poderia ser diferente, também fomos afetados, principalmente no último trimestre do ano. Entretanto, graças ao empenho, dedicação e muito esforço dos amigos associados estamos superando as dificuldades financeiras sem cancelar os objetivos assumidos com todos vocês.

Várias ações foram tomadas visando reduzir nossos custos fixos e aumentar a receita como, por exemplo, redução do aluguel da nossa sede em São Carlos, maior empenho na busca de novas empresas como sócios patrocinadores e coletivos, assim como solicitação a todos os Associados de uma doação no valor de uma anuidade.

A todos os Associados que demonstraram AMOR a nossa ABPol, o meu Muito Obrigado.

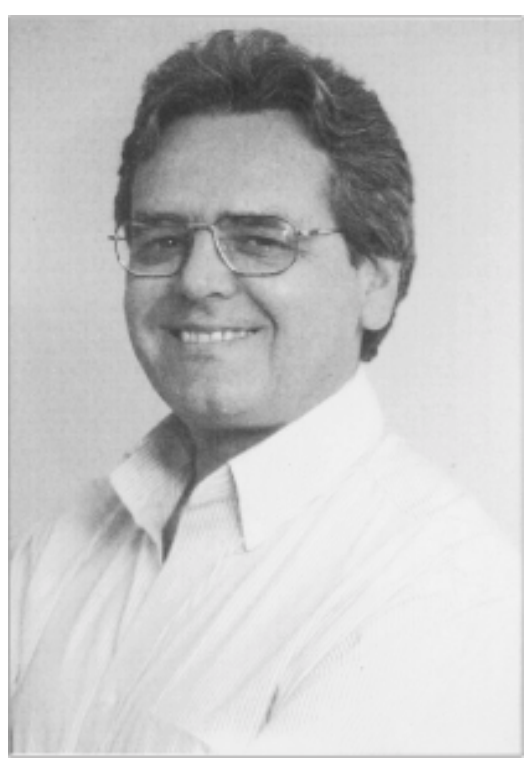

Em 99 as perspectivas, principalmente no primeiro semestre, não devem se alterar. Assim, a luta continua. Estaremos incentivando mais e mais empresas, estudantes e profissionais ligados à área de polímeros a se associarem. Promoveremos cursos rápidos "in company" de informações técnicas/ tecnológicas às empresas por um custo reduzido; motivaremos as empresas a participarem na edição Brasilplast da nossa revista e estaremos sempre abertos às idéias $\mathrm{e}$ sugestões de todos aqueles dispostos a lutar pela ABPol. Com a nossa determinação, coragem e vontade de vencer, não tenho a menor dúvida de que teremos muito sucesso.

Aproveito para desejar a todos, Funcionários, Diretores, Conselheiros, Líderes das Regionais e todos os amigos Associados um Ano Novo repleto de muita paz, saúde e realizações pessoais e profissionais.

Obrigado,

Edson Simielli

Presidente 